\title{
The investigation of the correlation between diastasis recti and the second stage of labor
}

\author{
Ersin Çintesun (iD), Meltem Aydoğdu (D), Çetin Çelik \\ Department of Gynecology and Obstetrics, Faculty of Medicine, Selçuk University, Konya, Turkey
}

\begin{abstract}
Objective: In our study, we investigated whether the distance between rectus abdominis muscles is correlated with the second stage of labor or not.

Methods: This is a prospective study conducted on the patients who underwent spontaneous vaginal delivery in our clinic between September 1, 2019 and December 31, 2019. Since these measurements were difficult during pregnancy, they were done after the delivery within postpartum 48 hours. The measurements were done on three anatomic areas, and the distance between rectus abdominis muscles and the thickest rectus muscle were measured by superficial ultrasonography. Xiphoid level, and $2 \mathrm{~cm}$ above and below the umbilical area were selected as measurement sites. Afterwards, the partographs in the patient files were checked to calculate the duration of the second stage of labor in minutes, and the correlation between these two values was calculated. The analyses of the patients collected for the study were calculated separately as primiparous and multiparous analyses.

Results: The data of 57 primigravid patients and 63 multigravid patients were compared. In the primigravid patients, there was a statistically significant weak correlation between the week of gestation, fetal weight and the distance between rectus muscles above xiphoid level and the second stage of labor $(\mathrm{p}<0.05 ; \mathrm{r}=0.351,0.369$, and 0.336 , respectively). No significant correlation was found between other ultrasonographic variables. There was a statistically significant weak correlation between the number of abortion and the second stage of labor in multigravid patients $(\mathrm{p}=0.002, \mathrm{r}=0.390)$. No significant correlation was found between the rectus muscles and fetal data and the second stage of labor in multigravid patients $(\mathrm{p}>0.05)$.

Conclusion: There was a significant correlation between the second stage of labor and the diastasis recti at the xiphoid level in primiparous patients. Further studies investigating the diastasis recti and intraabdominal pressure would help to determine the impact on the second stage of labor directly.
\end{abstract}

Keywords: Diastasis recti, labor, rectus abdominis.

\section{Özet: Diyastazis rekti ile doğumun ikinci evres arasındaki ilişkinin araştırılması}

Amaç: Çalışmada abdominal rektus kasları arasındaki mesafe ile doğumun ikinci evresi arasında ilişkinin olup olmadığı araştırılmışır.

Yöntem: Bu çalışma 1 Eylül 2019 - 31 Aralık 2019 tarihleri arasında kliniğimizde spontan vajinal doğum yapmış hastalar üzerinde yapılmış prospektif bir çalışmadır. Gebelik esnasında bu ölçümler teknik olarak zor olduğundan doğum sonrası postpartum 48 saat içerisinde ölçümler yapılmıştır. Ölçümler üç anatomik bölgeden yapılmış olup, yüzeyel ultrasonografi ile abdominal rektus kasları arasındaki mesafe ve en kalın rektus kası kalınlığı ölçülmüştür. Ölçüm yeri olarak ksifoid seviyesi, umbilikal bölgenin $2 \mathrm{~cm}$ üstü ve altı alınmıştır. Daha sonra hasta dosyasında bulunan partografa bakılarak doğumun ikinci evresinin kaç dakika sürdüğü hesaplanmış ve bu iki değer arasında ilişki hesaplanmıştır. Çalışma için toplanan hastaların analizleri primipar ve multipar olarak ayrı ayrı hesaplanmıştır.

Bulgular: Primigravid 57, multigravid 63 hastanın verileri karşılaştırılmıştır. Primigravidlerde gebelik haftası, fetal ağırlık ve ksifoid üzeri rektus kasları arasındaki mesafe ile doğumun ikinci evresi arasında istatistiksel olarak anlaml, zaylf derecede korelasyon saptanmıştır $(\mathrm{p}<0.05$ ve sırasıyla $\mathrm{r}=0.351,0.369,0.336)$. Diğer ultrasonografik değişkenler arasında anlamlı ilişki saptanmamıştır Multigravid hastalarda ise abortus sayısı ile doğumun ikinci evresi arasında istatistiksel olarak anlamlı, zayıf derecede korelasyon saptanmıştır ( $\mathrm{p}=0.002, \mathrm{r}=0.390)$. Multigravid hastalarda rektus kasları ve fetal veriler ile doğumun ikinci evresi arasında anlamlı bir ilişki tespit edilmemiştir $(\mathrm{p}>0.05)$.

Sonuç: Primipar hastalarda ksifoid seviyesindeki diyastazis rekti ile doğumun ikinci evresi arasında anlamlı ilişki saptanmıștır. İleriye dönük diyastazis rekti ile karın içi basıncının etkisini inceleyen çalışmalar, doğumun ikinci evresi üzerine etkisini de daha direkt belirlemeye yardımcı olacaktır.

Anahtar sözcükler: Diyastazis rekti, doğum, rektus abdominis.

Correspondence: Ersin Çintesun, MD. Department of Gynecology and Obstetrics, Faculty of Medicine, Selçuk University, Konya, Turkey. e-mail: ersincintesun@gmail.com / Received: January 21, 2020; Accepted: March 123, 2020

Please cite this article as: Çintesun E, Aydoğdu M, Çelik Ç. The investigation of the correlation between diastasis recti and the second stage of labor. Perinatal Journal 2020;28(1):23-27. doi:10.2399/prn.20.0281006 


\section{Introduction}

The labor is defined as the fetus going out of uterus after the regular contractions of uterus. The labor process has been defined in four stages. The first stage begins with the uterus contractions and cervical dilation and ends when the cervix is fully dilated. The second stage begins when the cervical dilation is $10 \mathrm{~cm}$ and it ends with the fetus moving through the birth canal. In the second stage of labor, fetal head makes the internal rotation in the mid-pelvis through uterus contractions and pushes and reaches right below the symphysis and after completing the internal rotation here, it goes out of perineum by performing extension. The second stage of labor is a significant milestone in the obstetric management, and its ideal duration has been still controversial today. ${ }^{[1]}$ Many factors affecting the second stage of labor have been defined. ${ }^{[2-5]}$ Among these factors, applying epidural anesthesia was shown to extend the second stage of labor. The position of mother and presence of pushes are among the factors that shortens the second stage of labor. ${ }^{[2,3,5]}$ Physiological pushing methods have been defined by the active directed pushing methods among today's pushing methods. $^{[6,7]}$ Physiological pushing methods are frequently today. ${ }^{[8]}$

Diastasis recti (DR) is the abnormal separation of the right and left rectus abdominis muscles at the linea alba level. Although there is no clear definition for the abnormal inter-rectus distance in DR, some authors consider the distances more than $2 \mathrm{~cm}$ as diastasis. ${ }^{[9]}$ However, it is clinically possible that there may be overt diastasis cases with inter-rectus distances less than $2 \mathrm{~cm}$. DR can be seen during pregnancy, postmenopausal period and in men..$^{[4]}$ In pregnancy, particularly DR occur physiologically and it may recover after delivery in some patients while it either progresses or remains same in some patients. Advanced age, multiparity, undergoing cesarean section, weight, high birth weight and ethnicity are the risk factors. ${ }^{[10,11]}$ Observing herniation in the inter-rectus distance through the increased intraabdominal pressure in case of DR indicated that DR may theoretically cause defect in the increase of intraabdominal pressure, and therefore it inspired us for this study.

In our study, we investigated whether the distance between rectus muscles is correlated with the second stage of labor or not.

\section{Methods}

This is a prospective study conducted on the patients who underwent spontaneous vaginal delivery in a tertiary university hospital between September 1, 2019 and December 31, 2019. The approval of the local ethics committee of the university was obtained before the study. The informed consents were received from the patients included in the study.

The pregnant women who underwent vaginal delivery between 37 and 42 weeks of gestation in our clinic were included in the study. The women who delivered at preterm and post-term weeks of gestation, those with known muscle and connective tissue diseases and the cases who underwent abdominal and cosmetic surgery were excluded from the study. Standard physiological pushing methods are used in our clinic as labor method, and the cases which were applied maneuvers that may shorten the second stage of labor were excluded from the study.

Since it was technically difficult to measure the distance between rectus muscles during pregnancy, these measurements were done within postpartum 48 hours. The measurements were done on three anatomic areas, and the distance between rectus muscles and the thickest rectus muscle were measured by superficial ultrasonography, and these measurements were done by the same physician. Xiphoid level, and $2 \mathrm{~cm}$ above and below the umbilical area were selected as measurement sites. Afterwards, the partographs in the patient files were checked to calculate the duration of the second stage of labor in minutes, and the correlation between these two values was calculated. The analyses of the patients collected for the study were calculated separately as primiparous and multiparous analyses.

The data were analyzed by using Statistical Package Social Sciences (SPSS), version 21.0 (SPSS Inc., Chicago, IL, USA). Histogram, Kolmogorov-Smirnov analysis and Scatterplots analysis were used for the normality and linearity analyses of the data. Where applicable, Pearson or Spearman's correlation analysis was performed for the correlation analyses. Statistical significance level was considered $\mathrm{p}<0.05$.

\section{Results}

The duration of the second stage of labor were compared separately in primigravid and multigravid 
Table 1. The correlation between diastasis recti and the second stage of labor.

\begin{tabular}{|c|c|c|c|c|}
\hline & \multicolumn{2}{|c|}{ Primiparity $(n=57)$} & \multicolumn{2}{|c|}{ Multiparity $(n=63)$} \\
\hline & $\begin{array}{c}\text { Full dilation time } \\
\text { r-value }\end{array}$ & $\begin{array}{l}\text { Full dilation time } \\
\text { p-value }\end{array}$ & $\begin{array}{l}\text { Full dilation time } \\
\text { r-value }\end{array}$ & $\begin{array}{l}\text { Full dilation time } \\
p \text {-value }\end{array}$ \\
\hline Age & -0.31 & 0.817 & -0.010 & 0.938 \\
\hline Gravida & - & - & 0.057 & 0.656 \\
\hline Parity & - & - & -0.218 & 0.087 \\
\hline Living & - & - & -0.218 & 0.087 \\
\hline Abortion & - & - & 0.390 & 0.002 \\
\hline Week of gestation & 0.351 & 0.007 & 0.155 & 0.226 \\
\hline Fetal weight & 0.369 & 0.005 & $0.020^{*}$ & 0.879 \\
\hline Distance between xiphoid rectus muscles & $0.336^{*}$ & 0.011 & $-0.076^{*}$ & 0.556 \\
\hline Thickness of xiphoid rectus muscles & $0.013^{*}$ & 0.921 & -0.027 & 0.836 \\
\hline Distance between xiphoid rectus muscles $2 \mathrm{~cm}$ above umbilicus & $0.217^{*}$ & 0.105 & $0.024^{*}$ & 0.853 \\
\hline Thickness of xiphoid rectus muscles $2 \mathrm{~cm}$ above umbilicus & 0.067 & 0.619 & -0.023 & 0.856 \\
\hline Distance between xiphoid rectus muscles $2 \mathrm{~cm}$ below umbilicus & 0.223 & 0.096 & -0.097 & 0.451 \\
\hline Thickness of xiphoid rectus muscles $2 \mathrm{~cm}$ below umbilicus & 0.032 & 0.814 & -0.094 & 0.461 \\
\hline
\end{tabular}

*Presented as Pearson correlation. Spearman's correlation was used for the other values.

patients. The data of 57 primigravid patients and 63 multigravid patients were compared. The correlation between 2nd stage of labor and DR, and demographic and fetal variables are summarized in Table $\mathbf{1}$. In the primigravid patients, there was a statistically significant, positive and weak correlation between the week of gestation, fetal weight and the distance between rectus muscles above xiphoid level and the second stage of labor ( $\mathrm{p}<0.05 ; \mathrm{r}=0.351,0.369$, and 0.336 , respectively). No significant correlation was found between other ultrasonographic variables $(\mathrm{p}>0.05)$. No correlation was found between the duration of the second stage of labor and the distance between rectus muscles, fetal weight and demographic data in multiparous patients.

\section{Discussion}

In this study, we investigated the correlation between the second stage of labor and the distance between rectus muscles. We found significant correlation in our study between the duration of the second stage of labor and fetal weight, week of gestation and the distance between rectus muscles at xiphoid level in primiparous patients. There was a significant correlation between the number of abortion and the second stage of labor in multiparous patients.
Diastasis recti is defined as the increase in distance between rectus muscles, and it develops the majority of the pregnant women. In the study performed by Hsia et al., the authors measured the distance between rectus muscles at 36 weeks of gestation and postpartum 12th weeks and found that difference was $300-400 \% .^{[12]}$ In another study, the authors made measurements through three different anatomic areas on 84 healthy primiparous patients and they followed up the cases at 35 weeks of gestation and postpartum periods for four times in terms of DR. In this study, the researchers considered $16 \mathrm{~mm}$ threshold value $2 \mathrm{~cm}$ below umbilicus for DR, and they established all patients with DR diagnosis at 35 weeks of gestation. However, the authors observed that this rate dropped to $35-39 \%$ in the ultrasonography performed on the postoperative sixth month. ${ }^{[13]}$ Also, there is no full consensus on the ideal DR distance. While some authors accept direct $2 \mathrm{~cm}$ threshold, some studies found different threshold values for DR distances. ${ }^{[14-16]}$ However, some studies based on symptoms found that DR symptoms were observed below $2 \mathrm{~cm}$ as well. ${ }^{[15]} \mathrm{DR}$ is an anatomic variability developing during the pregnancy according to the literature, and we investigated the correlation between DR distances and labor in our study. We did not use a cut-off value in our study considering the threshold values in the literature. There 
was a moderate and statistically significant correlation between the DR distance at xiphoid level in the primiparous patients and the second stage of labor in primiparous patients. However, we did not find any correlation in the multiparous patients.

In the literature, there is no study conducted on the labor outcomes of DR, and in fact, there is a limited number of studies on DR and pregnant women. Sperstad et al. investigated the correlation between DR and lumbosacral pain in the pregnant women in their study. They also assessed the patients 12 weeks later after the labor. In their study, the authors found DR prevalence between $30 \%$ and $45 \%$, and found no risk factor for DR except pregnancy, and could not observe any difference between the presence and absence of DR in terms of lumbosacral pain. ${ }^{[13]}$ In the study of Gannurson et al., the authors investigated the correlation between DR distance and abdominal muscle force. In this study, the authors measured muscular forces intraoperatively and found a significant and negative correlation between abdominal muscle force and DR distance. ${ }^{[17]}$ Benjamin et al. found no correlation between DR and lumbosacral pain and incontinence in their systematic review, but found a correlation between pelvic organ prolapse, quality of life, muscular force and severe back pain. ${ }^{[18]}$ The inspiration for our study is the investigation of the impact of muscle weakness caused by diastasis recti on the labor. In our study, we observed the impact of DR on the second stage of labor only at the xiphoid level in the patients with primiparity, but did not observe this impact on other levels in the patients with primiparity and multiparity. Indirect measurements without invasive methods can be misleading due to various reasons such as the presence of the impact of many factors on labor and the unknown impact of DR on the intraabdominal pressure.

Investigating the correlation between DR and the duration of the second stage of labor is the advantage of our study as it has not been investigated yet. Not measuring intraabdominal pressure, absence of data on DR and intraabdominal pressure in the literature the low number of patients included in the study are the limitations of our study.

\section{Conclusion}

In conclusion, we found a significant correlation between the second stage of labor and diastasis recti at xiphoid level in the primiparous patients. Moreover, we found a positive and weak correlation between the duration of the second stage of labor and week of gestation and fetal weight in the primiparous patient, which supports the study hypothesis. We found no correlation between the gaps above and below the umbilicus and the second stage of labor in the primiparous and multiparous patients. Further studies investigating the diastasis recti and intraabdominal pressure would help to determine the impact on the second stage of labor more directly.

Conflicts of Interest: No conflicts declared.

\section{References}

1. Cheng YW, Caughey AB. Defining and managing normal and abnormal second stage of labor. Obstet Gynecol Clin North Am 2017;44:547-66.

2. Gupta JK, Sood A, Hofmeyr GJ, Vogel JP. Position in the second stage of labour for women without epidural anaesthesia. Cochrane Database Syst Rev 2017;5:CD002006.

3. Lemos A, Amorim MM, Dornelas de Andrade A, de Souza AI, Cabral Filho JE, Correia JB. Pushing/bearing down methods for the second stage of labour. Cochrane Database Syst Rev 2017;3:CD009124.

4. Sperstad JB, Tennfjord MK, Hilde G, Ellström-Engh M, Bø $\mathrm{K}$. Diastasis recti abdominis during pregnancy and 12 months after childbirth: prevalence, risk factors and report of lumbopelvic pain. Br J Sports Med 2016;50:1092-6.

5. Tuuli MG, Frey HA, Odibo AO, Macones GA, Cahill AG. Immediate compared with delayed pushing in the second stage of labor: a systematic review and meta-analysis. Obstet Gynecol 2012;120:660-8

6. Hansen SL, Clark SL, Foster JC. Active pushing versus passive fetal descent in the second stage of labor: a randomized controlled trial. Obstet Gynecol 2002;99:29-34.

7. Maresh M, Choong KH, Beard RW. Delayed pushing with lumbar epidural analgesia in labour. Br J Obstet Gynaecol 1983; 90:623-7.

8. Hanson L. Second-stage labor care: challenges in spontaneous bearing down. J Perinat Neonatal Nurs 2009;23:31-9.

9. Akram J, Matzen SH. Rectus abdominis diastasis. J Plast Surg Hand Surg 2014;48:163-9.

10. Candido G, Lo T, Janssen PA. Risk factors for diastasis of the recti abdominis. Journal of the Association of Chartered Physiotherapists in Womens' Health 2005;97:49-54.

11. Turan V, Colluoglu C, Turkyilmaz E, Korucuoglu U. Prevalence of diastasis recti abdominis in the population of young multiparous adults in Turkey. Ginekol Pol 2011;82: 817-21. 
12. Hsia M, Jones S. Natural resolution of rectus abdominis diastasis. Two single case studies. Aust J Physiother 2000;46:3017.

13. Fernandes da Mota PG, Pascoal AG, Carita AI, Bø K. Prevalence and risk factors of diastasis recti abdominis from late pregnancy to 6 months postpartum, and relationship with lumbo-pelvic pain. Man Ther 2015;20:200-5.

14. Beer GM, Schuster A, Seifert B, Manestar M, Mihic-Probst D, Weber SA. The normal width of the linea alba in nulliparous women. Clin Anat 2009;22:706-11.

15. Keshwani N, Mathur S, McLean L. Relationship between interrectus distance and symptom severity in women with dias- tasis recti abdominis in the early postpartum period. Phys Ther 2018;98:182-90.

16. Akram J, Matzen SH. Rectus abdominis diastasis. J Plast Surg Hand Surg 2014;48:163-9.

17. Gunnarsson U, Stark B, Dahlstrand U, Strigård K. Correlation between abdominal rectus diastasis width and abdominal muscle strength. Dig Surg 2015;32;112-6.

18. Benjamin DR, Frawley HC, Shields N, van de Water ATM, Taylor NF. Relationship between diastasis of the rectus abdominis muscle (DRAM) and musculoskeletal dysfunctions, pain and quality of life: a systematic review. Physiotherapy 2019; $105: 24-34$.

Bu makalenin kullanım izni Creative Commons Attribution-NoCommercial-NoDerivs 3.0 Unported (CC BY-NC-ND3.0) lisansı aracılı̆̆ılya bedelsiz sunulmaktadır. / This work is licensed under the Creative Commons Attribution-NonCommercial-NoDerivs 3.0 Unported (CC BY-NC-ND3.0) License. To view a copy of this license, visit http://creativecommons.org/licenses/by-nc-nd/3.0/ or send a letter to Creative Commons, PO Box 1866, Mountain View, CA 94042, USA. 